\title{
Images of Revolution: An American Photographer in Petrograd, 1917
}

\author{
David H. Mould
}

"Well, I came to Russia against your wish and I am paying the price," Donald Thompson wrote his wife Dorothy (Dot) from Petrograd in late July 1917. "If I ever get back home safely, this is the last trip I shall make. . . . Today I feel as you always want me to feel-sick and tired of being a war photographer."1

Thompson had been away from home for almost eight months, and in Russia since mid- February. Over the next six months, he photographed demonstrations and street-fighting in Petrograd, was caught in crossfire between protestors and troops, and was arrested and thrown in jail. He travelled to Moscow and to the Russian front lines in Latvia. He met and photographed Tsar Nicolas II, political and military leaders, and prominent foreign visitors. He witnessed political maneuverings, the power struggle between the Provisional Government and the Petrograd Soviet, and the breakdown of discipline in the army. Often working late into the night, Thompson suffered from exhaustion, stress and poor diet. With food shortages, even in the hotels and restaurants patronized by foreigners, Thompson-already a lean 120 pounds-lost weight. Although he claimed he could live on bread and coffee, "the black bread that one gets now in Petrograd is one of the major horrors of war," he wrote. ${ }^{2}$ A few weeks later, he fell ill with a stomach infection and spent two weeks in hospital.

In late July, Thompson was ready to go home, but not ready to abandon the life of the "photographer-adventurer" that had taken him to every front in Europe since August 1914. After telling Dot that this would be his last trip, Thompson wrote: "But there is no use in saying this. I shall be the way I always have been. A few weeks at home and then I'll pick up the paper at breakfast and read about something happening somewhere and I'll want to go there."3

Donald Thompson in Russia is a compilation of letters to his second wife in Topeka, Kansas, written between December 12, 1916, and August 21, $1917^{4}$ and

1 Donald Thompson in Russia (New York: Century, 1918), 324.

2 Ibid., 34.

3 Ibid., 324.

4 Thompson's letters are dated by the Western Gregorian calendar, which ran 13 days ahead of the old-style Julian calendar used in Russia in this period. According to the Gregorian calendar, the events of the February Revolution actually took place in March, and those of the October Revolution in November. The introduction retains Thompson's 
published in 1918. It is impossible to know whether the letters are exactly what Thompson wrote at the time, or whether he edited them later to fill out the narrative and reinforce his central theme - that the major cause of Russia's revolution and withdrawal from the war was German intrigue. He claims in the introduction that "at the time they were penned the idea of writing a book had never entered my head." But he asked Dot to keep the letters and his motive for publication is clear. "When I came back from Russia, after one of the most exciting trips of my life, I was glad that I could show the whole world the proofs that German intrigue was the cause of Russia's downfall. German intrigue, working among the unthinking masses, has brought Russia to her present woeful condition." The letters, he added, "tell a story that I know a great many people may doubt. Fortunately, the details are largely substantiated by the motion-picture film I have shown in this country [The German Curse in Russia] supplemented by thousands of photographs which have appeared in "Leslie's Weekly" and in newspapers throughout the world." $" 5$

Thompson's letters are one of the few first-hand accounts by an American of events in Russia from late February to early August 1917. The photographer's experiences feature prominently in Helen Rappaport's recent book, Caught in the Revolution, that recounts the testimonies of foreign journalists, diplomats, businessmen, nurses and other others living in Petrograd in 1917. "It is a matter of considerable regret," writes Rappaport, "not to mention a loss to history and scholarship, that Thompson's original photographic negatives do not appear to have survived." The title of the book testifies to Thompson's zeal for self-promotion. Other expatriates wrote about their experiences in books with titles such as Runaway Russia, Six Red Months in Russia, Inside the Russian Revolution, Diary of the Russian Revolution, Unchained Russia, Russia's Agony, and, of course, Ten Days that Shook the World. Thompson's is one of only a few to include the name of the author in its title; in Donald Thompson in Russia, the author portrays himself not only as a witness to history, but as an actor in the drama.

Born in Topeka in 1885, Thompson worked as a freelance photographer, covering the 1903 Kansas River flood, the 1912 Democratic Convention, and the 1913 Colorado miners' strike. When war broke out in Europe, he was commissioned by a Montreal newspaper to film Canadian troops. It was his big break. "As a photographer," he wrote, "I knew it would be the greatest story in history and I determined that I was going to cover it. I sold everything I had, bought a complete photographic outfit and my steamship ticket." ${ }^{\text {"7 }}$ He sailed to Europe in August 1914.

The rapid growth of American mass media - newspapers, illustrated weekly magazines and motion pictures - in the first two decades of the $20^{\text {th }}$ century created new opportunities for news photographers. Most, like Thompson, began their

dating but refers to the February and October Revolutions, because this is how they are commonly termed.

5 Donald Thompson in Russia, xviii.

6 Caught in the Revolution: Petrograd 1917 (London: Hutchinson, 2016), 332-3.

7 Donald Thompson in Russia, vii. 
careers shooting stills for newspapers and magazines, and later shot film footage, using bulky, hand-cranked cameras mounted on tripods. The main customers for their films were the international newsreel companies, based in New York, Chicago, London, and Paris; several newspaper groups, notably the Hearst papers and the Chicago Tribune, also had interests in the newsreel business, as owners or part-owners of weekly reels. Footage was sometimes compiled into feature-length films. The rapid growth of the Hollywood movie industry gave newsreels and topical films thousands of theater outlets, and an audience for whom moviegoing was becoming a way of life.

The popular image of the brave, free-spirited news photographer, who defied danger, death, the elements and the censors to get the picture, was largely fashioned during World War One, when photographers faced all these obstacles. It was, like most such images, a composite of fact and fiction, so it is hardly surprising that, in recalling their exploits, photographers such as Thompson often added colorful details and dramatic turns. Thompson compensated for his less-than-imposing physical presence by portraying himself as a pioneer war photographer. He was proud to tell people he was from Kansas, a state which, with its rich and bloody history, seemed to symbolize the American frontier. The trade and popular press were willing accomplices in this reconstruction of reality, accepting the stories at face value, and often adding their own spice to the narrative. "Nearly every reader of news of the great European war is familiar with the name of Donald C. Thompson, known the world over as 'The War Photographer from Kansas,"” reported the trade newspaper Moving Picture World. "He is of a kind we sometimes read about but rarely collide with in the flesh." "' In Belgium, Thompson worked on both sides of the lines with Edward Alexander Powell, war correspondent of the New York World, covering the Battle of Mons and the German siege of Antwerp. "He was a slim, wiry little fellow, as hard as nails and as tough as rawhide," wrote Powell. "He wore riding breeches and leggins and was as bow-legged as though he had spent his life astraddle of a horse."10 The Chicago Tribune celebrated "Shrimp Thompson," the "young Topeka corn-fed product who has written K-AN-S-A-S across the war map of Europe." " Chicago Tribune London bureau chief Charles Wheeler admired "this devil-may-care, easy going, fear immune, quick witted, 120 pounds of human being," who was "equally at home on a gun carriage or in the swellest hotels of Europe ... joking with a king or getting joyously drunk with a trooper." ${ }^{12}$ Powell described their first meeting in Antwerp:

He blew into the Consulate wearing an American army shirt, a pair of British officer's riding breeches, French puttees, and

8 David H. Mould and Gerry Veeder, "The 'Photographer-Adventurers': Forgotten Heroes of the Silent Screen", Journal of Popular Film and Television 16 (Fall 1988).

9 Moving Picture World, February 6, 1915, 812.

${ }^{10}$ Edward Alexander Powell, Slanting Lines of Steel (New York: Macmillan, 1933), 46.

11 "Tribune Staff Men Off to War Zones," Chicago Daily Tribune, February 11, 1915, 5.

${ }^{12}$ Charles N. Wheeler, "Kansas Boy Likes the War," reprinted in Kansas City Star, January 29, 1915. 
a Highlander's forage cap, and carrying a camera the size of a parlor phonograph. Thompson is a little man, hard as nails, tough as raw-hide, his face perpetually wreathed in what he called his sunflower smile. He has more chilled-steel nerve than any man I know, and before he had been in Belgium a month his name became a synonym throughout the army for coolness and daring. ${ }^{13}$

Thompson's personal life enhanced his maverick image. He went through four marriages, and got into fistfights in hotel rooms and restaurants. He won and lost at the gaming tables, ${ }^{14}$ and was once arrested in Chicago for impersonating a naval officer and passing bad checks. ${ }^{15}$

Photographers such as Thompson presented themselves as experts on political and military matters. When his films were shown in major cities, Thompson appeared in military uniform (although he held no military rank) and told audiences that armies throughout Europe knew him as "le capitaine Thompson." souvenirs - passports, letters of authority, and medals - were displayed in the theater lobby, or in the window of a nearby store. He was a showman, often appearing in his own films. This device not only enhanced the film's authenticity - the image proved he was there- but showed its maker in suitable poses, preparing the camera for action, meeting the military brass, donning a gas mask.

World War One was the first major conflict to be covered by motion picture photographers. It was difficult, dangerous work. Thompson had to depend on the armies he worked with for access to the war zone, and faced a military bureaucracy that regarded photographers as, at worst spies and, at best dangerous nuisances. Military censors confiscated his cameras, or took out exposed film and held it up to the light to inspect it. Somehow, Thompson always managed to talk his way out of trouble and resorted to elaborate schemes to smuggle his film back to London or New York. ${ }^{17}$ In the war zone, he was subject to military authority - the armthat provided him with food and transportation determined where he travelled, and what he shot. He was in as much danger as a regular soldier, sometimes more, because a camera could be mistaken for a new-fangled gun, and invite an artillery barrage. Several photographers were killed, and others, including Thompson, wounded. Most of his footage was taken behind the lines; it shows military parades and ceremonies, the build-up of troops and supplies, airplanes and observation balloons, artillery barrages, prisoner-of-war camps. The few front-line scenes show a featureless landscape, broken only by the distant explosion of artillery

${ }^{13}$ Edward Alexander Powell, Fighting in Flanders (New York: Charles Scribner and Sons, 1916), 13-14.

${ }^{14}$ En route to Russia in early 1917 , he claimed to have made $\$ 8,000$ on the roulette tables in a Shanghai casino, after starting with a $\$ 120$ stake. "That will buy a lot of nice presents for you," he wrote Dot (January 22, 1917).

${ }_{15}$ Topeka State Journal, June 5, 1923, 1.

16 "Thompson Tells Tales of Battle," Topeka Daily Capital, December 30, 1915.

${ }^{17}$ Powell, Fighting in Flanders, 15; Kansas City Star, September 6, 1914. 
shells. Indeed, the best times for fighting - in the dark or under smokescreenwere the worst times for photography; when the sun was shining and the light was good, there was not much going on. World War One, as Thompson saw and filmed it, was nothing like the Hollywood version, full of cavalry charges and desperate hand-to-hand combat. ${ }^{18}$

During the first year of the war, Thompson shot stills for American and British newspapers and magazines - the New York World, the Chicago Tribune, Leslie's Illustrated Weekly, the London Daily Mail, the Illustrated London Newsand film for the major newsreel companies. His early experiences on the Western Front set the tone for the rest of his career. In his attempts to reach the front lines, he was frequently arrested. At the Battle of Mons, he filmed under heavy fire for seven days, was again arrested, and ordered to leave the country. Fearing his film would be confiscated, he persuaded a Russian countess travelling to England to carry it in her baggage. In London, he sold the film to the highest bidder, and then went back to the front. ${ }^{19}$ On his return to London, Thompson was hired by the newspaper magnate Lord Northcliffe to go to Germany. They made up a fake newspaper clipping from a non-existent American newspaper, in which Thompson praised the German army in Belgium. He managed to reach Berlin, but a German spy in London tipped off the secret service, and Thompson had to make a quick getaway. He looked up a girlfriend, and proposed they elope; she got a passport for her "brother" and they drove to the border. There, the ungallant Thompson confessed that he was not in love after all, and left her. ${ }^{20}$

Thomson made his first trip to Russia in 1915. In February, he sailed to Europe with Robert R. McCormick, editor of the Chicago Tribune, and Edwin Weigle, a Tribune photographer. After a brief stay in England and France, Weigle went to Germany while McCormick and Thompson traveled east via Greece, Bulgaria and Rumania, arriving in Petrograd in early April 1915. McCormick was granted a short audience with Tsar Nicolas II, which he remembered mostly for the pomp and circumstance - the coaches, liveried footmen, uniforms, furniture, paintings of Louis XIV. "I felt like Marco Polo at the court of the Chinese emperor," he wrote later. ${ }^{21}$ Then the pair travelled to the front in Galicia and the Carpathian Mountains, where in late 1914 the Russians had launched a successful offensive against the Austro-Hungarian army and laid siege to the strategic fortress of Przemysl on the road to Krakow. The fort surrendered in March 1915 with the Russians taking 120,000 prisoners and capturing 1,000 artillery pieces. The victory was short-lived. By the time McCormick and Thompson reached the front, the Russians were facing a combined German-Austrian offensive that ended with victory at the Battle of Gorlice-Tarnow in May. This turned into a strategic retreat, with the Russians withdrawing from Poland, and removing the threat of an

${ }^{18}$ David Mould, American Newsfilm, 1914-1919: The Underexposed War (New York: Routledge, 2014), 100-114

19 Powell, Fighting in Flanders, 15.

${ }^{20}$ Topeka Daily Capital, December 30, 1915; Donald Thompson in Russia, xi-xii.

${ }^{21}$ Robert R. McCormick, With the Russian Army, Being the Experiences of a National Guardsman (New York: MacMillan, 1915), 37. 
invasion of Germany or Austria-Hungary. The Russians had welcomed the wellconnected McCormick, whose father had been U.S. ambassador in Petrograd, as an unofficial U.S. emissary. As Thompson noted: "Mr. McCormick had letters of introduction, passes to every country in Europe, and was received as no other war correspondent has ever been received during this war. Wherever he appeared the government officials went out of their way to assist him." ${ }^{22}$ McCormick's memoir recounts meetings with politicians, strategy discussions with the General Staff, and lavish dinners with caviar and French wine. Traveling with him, Thompson would have had little opportunity to observe the conditions of the regular troops.

Thompson's footage was released by the Chicago Tribune as a feature-length film, With the Russians at the Front, in August 1915, followed a week later by the premiere of Weigle's The German Side of the War. Neither made any pretense of neutrality. Although the Russian army was in general retreat from Poland, With the Russians at the Front portrayed it as a formidable war machine. ${ }^{23}$ The Chicago Tribune full-page display ads promised exclusive footage:

Positively the only motion pictures taken within Russian lines made under the personal supervision of R.R. McCormick, war correspondent, and Donald C. Thompson, staff photographer. The Chicago Tribune received the EXCLUSIVE PERMISSION of the Russian government to photograph the very recent Russian campaigns in the Carpathians, on the Rawka River, at Przemysl, Warsaw. Be an eye-witness of the Russian armies in the field-under fire - in the rain-soaked trenches of the Polish front - taking up positions in the mountains. Approach within a few feet of the Czar of All the Russias. See that spectacle - the Imperial Guard in battle before Lomza. ${ }^{24}$

Only 23 minutes of the film have survived, and some scenes promoted in the advertising are missing. ${ }^{25}$ Thompson faced the same logistical problems he had encountered on the Western front-lack of access to the war zone and, even if he reached it, lack of action. Consequently, most of the footage was taken behind the lines. The film opens with Thompson and McCormick posing by a car with a Chicago Tribune banner. There are scenes from staff headquarters showing Grand Duke Nicolas, the commander-in-chief, the Tsar reviewing troops, General Aleksey Brusilov, commander of the $8^{\text {th }}$ Army, artillery batteries in action in the Carpathian Mountains, Cossack cavalry on parade, field hospitals and kitchens,

${ }^{22}$ Donald Thompson in Russia, xii-xiii.

${ }^{23}$ Historians attribute Russia's defeat on the Eastern Front not so much to strategy as to lack of artillery, ammunition and supplies as well as the corruption and incompetence of Russian officers. McCormick refers to the lack of railways as an infrastructure problem, but in the film's titles and in his later memoir, With the Russian Army, provides positive assessments of the Russian army and the competence of its officers.

${ }^{24}$ Chicago Daily Tribune, August 22, 1915, 10.

${ }^{25}$ A print of the film is in the Film Study Center at the Museum of Modern Art in New York. 
and refugees. The only "front-line" scene features the Seminovsky Regiment of the Imperial Guard at Lomza. It shows soldiers running past a building and firing from a parapet; some fall back, apparently wounded, and are carried away on stretchers. As McCormick noted, Thompson filmed during a break in the fighting, and all the scenes were staged for the camera. ${ }^{26}$ Given the difficulty of obtaining combat footage, such staging, with the willing assistance of military officers, was common during World War One. To satisfy audience demand for war footage, Thompson organized infantry to march, cavalry to charge, artillery to fire and airplanes to take off and land.

Like McCormick, Thompson left Russia in 1915 with a positive view of its military command and government. He also made contacts he would use in 1917, including his interpreter, Boris. He was aware of supply problems, commenting later that munitions production had improved. "I find the Russian troops much better equipped now than in 1915, and ammunition is plentiful, artillery ammunition, especially. Shells are stacked up wherever you go" (February 28, 1917). If he was aware of corruption and incompetence in the army, he did not mention them in interviews with the motion picture and popular press. Reflecting on the 1915 trip in the introduction to Donald Thompson in Russia, Thompson says that he did not understand why the Russian armies with their "millions of men" did not "push the German army aside and go where they pleased." The reason, he was told, was German intrigue. A Cossack officer in the Carpathians said Russia was "paying the price" for not locking up its German-born citizens whose bribery and intrigue were undermining the war effort. "Their generals were bought, their ammunition was going astray, and they were losing thousands of men in fruitless battles ... They caused thousands to die in hospitals, for while millions had been appropriated for field hospitals, German intrigue had diverted that money into other channels. ${ }^{27}$

Thompson goes on to attribute most setbacks in the Allied war effort to German intrigue. In Bucharest, Germany had "thousands of spies on her pay-roll"; Serbia was defeated "partly by the devious methods that Germans love and excel in"; in Rome, an Italian officer told him that Italy's "wonderful army" would be thrown back "because there were too many Germans running loose in the country, doing the dirty work of the Kaiser." Every Allied country Thompson had visited that "had not locked up its Germans, has since felt the disastrous effect of the Teutonic spy system."28

While McCormick returned to the U.S. from Russia via Sweden, Thompson traveled south to the Balkans. On July 23, 1915, the U.S. legation in Athens wired McCormick, relaying Thompson's request for $\$ 500$ to travel home. McCormick, already frustrated by Thompson's cockiness, insubordination and occasional drunkenness, refused. He wired back the next day: "Please take all moving picture apparatus film and cameras from Thompson. Buy him third class ticket

${ }^{26}$ The Papers of Colonel Robert R. McCormick, Cantigny Park, Illinois: notes for lecture at film premiere at Studebaker Theater, Chicago.

${ }^{27}$ Donald Thompson in Russia, xiii-xiv.

${ }^{28}$ Donald Thompson in Russia, xv-xvi. 
to America and give him ten dollars. Don't lend Thompson any money." A week later the legation reported, "Thompson refused your offer. Got money somewhere and left for France with apparatus." ${ }^{29}$

Thompson spent the next few weeks filming with the Serbian army. By Fall 1915, he was back in France, still posing as a Tribune photographer and running up hotel bills that McCormick eventually had to pay. He released his first featurelength film, Somewhere in France (the title is an allusion to the censors' ban on revealing place names) in December 1915, then returned to the Balkans where the Allies had opened a new front at Salonika. Then he joined the French army as an official cinematographer; although his status provided access to the front, he had to submit his film for censorship, and claimed he lost 70 per cent of his footage. ${ }^{30}$ He filmed at the siege of Verdun and Battle of the Somme, where he was wounded. His second feature, the immodestly-titled War As It Really Is, was released in December 1916. Its premiere at the Rialto Theater in New York City broke the box office record. ${ }^{31}$ By the end of 1916, Thompson had worked on every front in Europe, claimed to have witnessed 38 battles, and had been wounded three times. His hometown newspaper, the Topeka Daily Capital, sponsoring the local premiere of War As It Really Is, praised him as "the photographic hero of the war." 32

In December 1916, shortly after the release of War As It Really Is, Thompson, on assignment to shoot film for Paramount and stills for Leslie's, left Seattle on the liner Empress of Russia for Japan, accompanied by Leslie's Weekly staff correspondent Florence Harper. He found plenty of evidence to support his German conspiracy thesis on the long journey to Petrograd. On the ship, a Russian army officer told him that intrigue in the Imperial Court had undermined military assistance to Rumania, forcing its armies to retreat and abandon Bucharest (December 12, 1916); in Manila, Thompson filed a libel suit against a newspaper editor who he suspected of being paid by the Germans over an article claiming that Thompson and Harper were impostors (January 5, 1917); Shanghai was "a regular pest-hole for German spies" (January 22); in Peking, he punched a hotel manager when he surprised him going through his baggage and papers (February 14); on the Trans-Siberian Railway, fellow passengers told him that German agents were creating food shortages in Petrograd to foment riots (February 24).

Thompson and Harper worked together for six turbulent months as the country plunged into political and social chaos. They covered the protests and streetfighting of the February Revolution that ended with the Tsar's abdication and the establishment of the Provisional Government, and the abortive Bolshevik coup in July. They travelled to the front line, where discipline was breaking down and

${ }^{29}$ The Papers of Colonel Robert R. McCormick, Cantigny Park, Illinois: I-62, Foreign Correspondents, 1914-1955, Box 11, Donald Thompson.

30 "Real Thrills in Battle Pictures," Moving Picture World, November 11, 1916, 857.

31 "War Films on State Rights from Thompson Company," Motion Picture News, December 2, 1916, 3453. For a review of War As It Really Is, see "Real Thrills in Battle Pictures," Moving Picture World, November 11, 1916, 857. A copy of the film is in the National Archives.

${ }^{32}$ Topeka Daily Capital, December 21, 1915. 
soldiers' committees were being formed. They left Russia in August, missing the main event - the October Revolution.

Thompson sensed that he was in Russia at a historic time. "So far, Dot," he wrote on March 8, "I have guessed this war to a T. The people can say what they please, but I smell trouble. And thank God I am here to get the photographs of it! If there is a revolution I hope it comes now, for although I should hate to see bloodshed, if it has to be it might as well come while I am on the ground with plenty of film." 33 On March 18, after the Tsar's abdication and the declaration of a republic, he wrote: "Just imagine if someone had had the French Revolution in motion pictures! Well, I have thousands of feet of film of the Russian Revolution. I have worked every day and have followed the mobs day and night. I went seventy-two hours without any sleep at all to speak of . . . but I got my film and hundreds of still pictures." 34

His letters recounted daring photographic exploits under fire. With his flair for self-promotion, he may have exaggerated the stories but there is corroboration from other sources, particularly the accounts of newspaper correspondents who worked with him. His closest associate, Harper, wrote articles describing the same incidents, and published a memoir on her Russian experiences, Runaway Russia. ${ }^{35}$ In an article for the London Daily Mail, reprinted in American newspapers, she recounted a typical piece of Thompson derring-do during the abortive Bolshevik rising in July:

Tuesday morning the Nevsky was said to be very unsafe, so Thompson piled his camera into a big auto, and said, "Come on." He was in khaki; on the front seat his orderly and the chauffeur were both in uniform. I wore a blue Italian army cape, so we looked rather military. The tripod of the camera sticking up in the tonneau looked not unlike a new kind of gun. In fact it looked so dangerous that it gave us a clear passage up the Nevsky. As we neared the corner of the Liteiny the crowds were thick, and soon the trouble started. The Bolsheviki met the Cossacks, both armed and with machine guns on both sides. Thompson set up the camera and began to crank. One minute the street was a mass of people, the next they had fallen flat to escape the bullets or were running for cover. All the time Thompson cranked away. His coat was off, and strapped to his belt was an Army colt. The chauffeur showed signs of panic. Thompson drew his gun, and said, "You do as I tell you, or you'll get shot, too." ${ }^{36}$

\footnotetext{
${ }^{33}$ Donald Thompson in Russia, 47.

${ }^{34}$ Ibid., 74.

${ }^{35}$ Florence MacLeod Harper, Runaway Russia (New York: Century, 1918).

36 "Thompson Risks Life to Film Russian Revolution Scenes," Topeka Daily Capital, September 30, 1917.
} 
Accounts of this incident appear in several sources, delivered in the same kind of breathless prose and with only minor variations in detail; if it seems a little farfetched, at least everyone was telling the same story. ${ }^{37}$ This was just one of many incidents recounted by Thompson and Harper, but unfortunately, there are few surviving stills to document them.

Thompson's accounts are rich in detail; he almost always included the date, the time of day, and locations, noting, for example, the direction in which a crowd was moving, or where he was when an incident occurred. Most events happened in central Petrograd, and so, by referring to a map of the city, it is possible to plot the action. However, Thompson's estimates of crowd size are unreliable. Describing a demonstration by women and factory workers on March 8, he noted that the crowd "soon numbered at least 2,000." A week later, on the Liteiny and "found a mob of about a million people, it seemed to me; and this mob was out for blood" (March 18). "There were fully 75,000 people packed in the square in front of the Duma," he reported the next day. "There were half a million people in line, men and women and soldiers" in the May Day Parade, and "in one division 15,000 anarchists." The next day, on the Sadovaia, Thompson and his interpreter Boris "met a mob of about 10,000." He estimated that "about a million people" attended the funeral for Cossack soldiers killed during the abortive July coup. Estimating crowd size is a professional skill, and is best done from a vantage point. At street level, it is virtually impossible to estimate numbers, yet Thompson consistently did so, even when he was lying prone on the ground. Caught in crossfire near the Summer Palace during the abortive coup in July, Thompson and Boris threw themselves to the ground. "We had company, however," wrote Thompson, "between these two points, there must have been between 1,800 and 2,000 people lying flat on the street." 38

Thompson spoke only a few words of Russian so relied on his interpreter, Boris, and other English speakers, not only to translate but to interpret events and reports. Of course, Thompson had other sources - fellow journalists and photographers, military officers at the Astoria Hotel, American embassy staff. Harper spoke French, which allowed her to converse with some military officers and government officials. Boris, however, was with Thompson most of the time. On the streets of Petrograd, Boris told him what people were saying, what their banners and signs meant, what the newspapers were reporting.

We know little about Boris, except that he was conscripted into the Russian army in 1916 and wounded on the Rumanian front. He complained to Thompson about lack of munitions and food at the front, and the disorderly retreat. Clearly, Boris was disillusioned with the Tsarist government, and warned Thompson that food shortages and strikes in Petrograd would lead to trouble. He told Thompson that secret police were acting as provocateurs, mingling with the crowds and incit-

${ }^{37}$ A similar account of the incident described Thompson's actions as in character. "Americans who saw Mr. Thompson shouted to him that he must be crazy. But he had gone all over Europe taking war pictures and he wasn't going to be balked here." "Lenine Anti-American as Well as Pro-German," New York Times Magazine, 8.

${ }^{38}$ Donald Thompson in Russia, 43, 80, 108, 156, 162, 337, 288. 
ing demonstrators to violence and looting to provoke an armed response by the Cossack cavalry or Imperial Guard. On April 4, Boris reported that "German spies are spending money here in Petrograd as they never spent it before" and "thousands of Germans are coming into Russia now from Sweden on forged passports and by bribing officials at the border." 39

Boris was most reliable in reporting what was happening on the streets of Petrograd. His assessments of the political and military situation or the maneuverings between rival factions were more speculative, yet Thompson frequently included them in his letters. "The revolution isn't two weeks old yet and already they are fighting amongst themselves," he wrote on March 21. "As things stand now, all are in favor of the republican form of government, such as we have in the United States. I hear through Boris that this is the sentiment in all the large cities." ${ }^{40}$ Boris told him that most people on the streets had no idea of why they were protesting. "I ran across one mob of 10,000 workmen, 80 per cent. of them armed; when Boris asked a few of them what they were out for, they didn't know; they only showed him a printed slip, telling them to be at a certain place at a certain time. Take it from me, this Lenin has certainly got these people well trained considering the short time he has been back in Russia."41

Just before the abortive Bolshevik coup in July, Thompson wrote that he had "made photographs of Lenin and a man named Trotsky who has come from New York" at the Bolshevik headquarters, the Kschessinskaya Mansion. Lenin is mentioned in three photograph captions in the book. "Lenin addressing a Petrograd mob, Monday, July 16, 1917" and "Lenin's arrival in Petrograd" are crowd shots in which the Bolshevik leader cannot be identified. ${ }^{42}$ The photograph captioned "Trotzky and Lenine" shows a group of six men and two women, with soldiers in the background. ${ }^{43}$ Trotsky and Lenin are not identified but part of the photograph, reproduced in the Illustrated London News, December 15, 1917, names the men on the far right as Trotsky and Lenin. This image, writes Mike Carey, appeared "in large-circulation journals ... most often alongside the argument that the two revolutionary leaders were either working for Germany or were even secretly Germans themselves." 44

The men pictured are not Trotsky and Lenin, and bear little physical resemblance to them. Few images of the Bolshevik leaders were in circulation at the time, so Thompson's photograph was accepted for what it purported to be. As his earlier career indicates, Thompson had few qualms about staging and even fak-

\footnotetext{
${ }^{39}$ Ibid., 140.

${ }^{40}$ Ibid., 123.

${ }^{41}$ Ibid., 181.

${ }^{42}$ Ibid., 279, 303.

43 Ibid., 173.

${ }^{44}$ Mike Carey, "Definitely Not Lenin and Trotsky: Donald C. Thompson's Photographs of 1917," European Studies blog, British Library, January 4, 2016. According to Carey, a French series on Soviet history published in the early 1920 s identifies the "Trotsky" figure as Mikhail Martynov, chair of the Kronstadt Soviet, and the "Lenin" figure as Christian Rakovsky, a Bulgarian socialist revolutionary who moved to Petrograd and joined the Bolsheviks in spring 1917.
} 
ing scenes, and he would have known that a picture of the mysterious Bolshevik leaders would be a scoop for Leslie's. Yet he may simply have been deceived by Boris or one of Bolsheviks. Or perhaps, as Carey suggest, Lenin and Trotsky were "using body doubles, political decoys." We may never know.

Many of Thompson's letters mixed personal experiences with what he learned, often second or third hand. Almost every day, he heard unconfirmed reports and rumors, and freely admitted that sometimes he did not know what to believe. Soon after his arrival in Petrograd, he wrote: "Boris says a revolution is coming and he has heard that Protopopov has sold Russia to Germany, that he is going to make peace and that there will be lots of food in a few days. I asked him where he got this information and be said he couldn't tell me but that I would hear it from other people." "The papers are full of what the members of the Duma and the different committees are saying, what they want, and what Russia should have, until you never know what to believe," he wrote on April 4. "It seems that every political party has a paper now. Since Russia is a republic everyone lets off steam." 46 Shortly before his departure, he wrote: "I hear that Kerensky had a fight with one of the ministers of the cabinet, and that for a while we had no government at all, and that Kerensky had even rushed away to Finland in an automobile. How true this is I don't know, but I do know that all the ministers resigned but later reconsidered and withdrew their resignations." ${ }^{47}$

Despite the rumors and his reliance on Boris and other sources, Thompson correctly interpreted, in his own homespun style, several key issues. He grasped that the future of the February Revolution would be decided in a power struggle between the Provisional Government, backed by the Duma, and the Petrograd Soviet of Soldiers' and Workmen's Deputies. He described the members of the Soviet as "the orneriest bunch of devils I have ever met. I will bet $\$ 1,000$ to a cent that 90 per cent of them cannot read or write, but they are being led by some pretty smart people. They are handing out proclamations every five minutes to appeal to the rabble they represent." ${ }^{48}$ He understood the crucial linking role that Kerensky played as the only political leader to serve both as a minister and an elected member of the Soviet; later, he predicted that the rivalry between Kerensky and General Lavr Kornilov, the army commander-in-chief, would be a deciding factor. However, his deference to royalty (he had met and photographed the Tsar in 1915) clouded his judgment. Learning of the Tsar's abdication, he wrote: "I believe that if he could have been in the city Monday and had driven down the main street of Petrograd, the Nevsky Prospekt, and stood up in the back of his automobile with his hat off and talked, as Teddy Roosevelt would have done, he would still be the Tsar of Russia. He could have had the people with him and all that he would have had to do would have been to grant what the people wanted, to see to it that bread was brought into Petrograd, and to appoint new ministers. . . . As it was, he

\footnotetext{
${ }^{45}$ Ibid., 38-39.

46 Ibid., 139.

${ }^{47}$ Ibid., 340.

${ }^{48}$ Ibid., 103.
} 
did nothing; why, I do not know. Probably because royalty doesn't do things that way." 49

Thompson reserved his sharpest criticism for Lenin and Trotsky- the two principal villains in the plot. Lenin had returned from exile in Switzerland in April. "Lenin might say that he is not in the pay of the Germans," he wrote, "but take it from me, Germany is not giving a special car to anyone to travel through Germany and back to Russia who is at war with them." At the same time, he grudgingly admired Lenin's political acumen. "Lenin is a brilliant man and is smart enough to know what the poor Russian wants to hear. These poor fellows believe that if Lenin is put in power the war will stop, the land and all the money will be divided amongst them, and they will never have to work again." ${ }^{50} \mathrm{He}$ wrote that Lenin was gaining support, and predicted that if he was not killed or jailed, he would soon be running Russia - a pretty accurate forecast for six months before the October Revolution.

Thompson made several trips to the front line which, after the retreat from Poland, ran roughly north-south-from Riga in Latvia, 300 miles southwest of Petrograd, to northern Rumania. He blamed German propaganda for disaffection and desertion in the army. "The Russian does not really know what he is fighting for," he wrote. "Nobody had ever told him what the war was about. . . . Now the Russians are leaving the trenches and the camps and wandering over the country trying to find their way back to their homes (most of them don't know how to get back home). They hear about peace, and they know that means they will not have to lie in the trenches this coming winter." Thompson believed Russia's generals could restore morale by ordering a new advance. "What Russia needs at the front is a leader, a Napoleon, someone who has the nerve to do things, no matter what the public says or how many mobs appear on the streets of Petrograd." 51

Thompson returned to the United States in September 1917 as the Allies faced the prospect of Russia's withdrawal from the war and the collapse of the Eastern Front. The Allies feared that American troops would not arrive on the Western Front in time to stem a new German offensive. With the American press and public concerned by events in Russia, it was tempting to look for villains. The movie industry conveniently provided them in Thompson's feature-length film, The German Curse in Russia (also known as Blood-Stained Russia). It was released to enthusiastic reviews in December 1917, the same month that Russia withdrew from the war and the Germans occupied the Ukraine. Its title summarized its theme - that the revolution was a giant conspiracy, fomented by German intrigue, and its leaders, Lenin and Trotsky, were spies and rabble-rousers, hired by the Germans to incite the people. According to Motion Picture News, "Every foot of the film helps to visualize for the American people the means that the Germans utilized in Russia to bring about food riots, street fighting and the final overthrow of the government which had been established for them upon a foundation

\footnotetext{
49 Ibid., 114, 117.

50 Ibid., 159-160.

51 Ibid., 195-196.
} 
of freedom and liberty." ${ }^{52}$ Moviegoers were promised "the inside truth about Russia, showing how German intrigue, stopping at nothing, drove the Russian people to revolt and put their armies out of the war." ${ }^{53}$ Moving Picture World told theater managers that The German Curse in Russia would play on the patriotic fervor of their patrons, suggesting they hold free performances for schoolchildren and their teachers, and drape the lobby with American and Russian flags. ${ }^{54}$ Thompson was treated as an expert witness, whose views on the situation in Russia should be taken seriously. According to Picture-Play Magazine, Thompson felt his mission was not only to observe but to warn. "He realized that he had been doing something more than merely taking war pictures. He saw that within his films lay concealed the pitiful story of how German intrigue had sapped a great nation. And he realized, too, that this story was needed in America as a timely warning." ${ }^{55}$

Did The German Curse in Russia live up to its claims? Was it, as its distributor Pathé claimed, "the greatest of all war pictures"? We may never know because the film has apparently been lost. ${ }^{56}$ However, the themes of the film, as reported in the press, are similar to those outlined in Donald Thompson in Russia and in Thompson's still photographs. For nine months, from June 1917 to March 1918, Leslie's featured full-page or double-page spreads of Thompson's photographs, often with copy by Harper. The headlines played on anti-revolutionary sentiment in the United States- "Bolshevism-Talk, Poverty, Arson and Murder," "The Evil Reign of Russia Bolsheviki," "Bitter Lessons in Bolshevism," "No Peace for Struggling Russia." Some stills appeared in the motion picture trade press, in Thompson's and Harper's books, and in a book of his photographs. ${ }^{57}$ As in Thompson's films, the images do not speak for themselves; it is the titles and captions that provide context and political perspective.

The claims by Thompson and others that German intrigue was the principal cause of the October Revolution were widely aired in the popular press of the United States, and supported by government officials and opinion leaders. In March 1918, Edgar Sisson, an American journalist serving as representative for the Committee on Public Information (CPI) in Petrograd, returned to the United States with documents purporting to show that the Bolshevik regime was a puppet government controlled by the German general staff. The head of the CPI, George Creel, told President Woodrow Wilson that the documents revealed an "amazing record of double dealing and corruption" that would constitute a coup for American propaganda. After a hurried and uncritical review, the government published them under the title, The German-Bolshevik Conspiracy. ${ }^{58}$ Although many of the

52 "Pathé Shows Good War Films," Motion Picture News, December 29, 1917, 4535.

${ }^{53}$ Canadian Moving Picture Digest, February 9, 1918, 14.

54 “Advertising Aids for Busy Managers," Moving Picture World, January 26, 1918.

${ }^{55}$ Louis Tenny, "Filming the Trail of the Serpent," Picture-Play Magazine, March 1918, 113-14.

${ }^{56}$ Sadly, no prints of the film appear to have survived although some footage - apparently purchased from Thompson-was re-used in Herman Axelbank's 1937 documentary compilation, From Tsar to Lenin.

${ }^{57}$ Blood-Stained Russia (New York: Leslie-Judge Co., 1918).

${ }^{58}$ George Creel to Wilson, May 9, 1918, Box 2, Creel Papers, Library of Congress. 
documents were later shown to be forgeries, they made excellent propaganda, providing a suitably dastardly explanation for Russia's departure from the war. The simple conspiracy theory provided a convenient fiction to explain a series of events that Americans found confusing and threatening. Thompson's views were shared by many other Americans.

Thompson did not believe that this regime of revolutionaries and German spies could last long, and he expected a counter-revolution. "The thing that will conquer Lenin and his Bolsheviki," he said in March 1918, "is an army from outside Petrograd, an army that really represents Russia." 59 That army soon appeared, as counter-revolutionary White forces attacked Bolshevik forces in Siberia. The Allies sent an expeditionary force to support the White Armies, and Thompson landed at Vladivostok ready to film the triumphal advance to

Petrograd. It never happened. The White armies were too busy arguing among themselves to mount a concerted offensive, and the Allied force was unable to advance from Vladivostok. Thompson spent several frustrating months filming military parades and relief efforts for refugees. The Allied force was withdrawn in late 1919, but Thompson's experience only served to confirm his opinions; photographs of the Allied force and the White Armies, published in Leslie's Weekly, provided what he judged to be further proof of German intrigue and the evils of Bolshevism. $^{60}$

Details of Thompson's postwar career are sketchy. In 1920, he left for a year's tour of the Far East, with a commission from the magazine Asia to shoot stills and motion pictures of native life in 15 countries, from Mongolia to Borneo. ${ }^{61} \mathrm{He}$ settled in Hollywood, and married for the third time. Throughout the 1920's and 1930's, he worked as a freelancer, selling topical films and travelogues. In 1927, he travelled to the Philippines and China, accompanied by his new wife, Maria. He dutifully recorded the usual travelogue scenes, such as the Great Wall and the Summer Palace in Peking, and then began work on a more controversial subject - the Chinese drug trade. The British authorities in Hong Kong, who quietly permitted the drug traffic, did not want a film exposé, and Thompson became an unwelcome visitor. They confiscated some of his film, but he held onto enough footage to produce a topical feature on the drug traffic and opium addiction. ${ }^{62}$

In the 1930's, Thompson filmed the Japanese invasion of China, the German occupation of Austria, the Italian campaign in Ethiopia, and the Spanish Civil War. Visiting St. Joseph, Missouri, in 1937, the "adventurer-correspondent" described meetings with Hitler and Mussolini, and offered a comparison of how they handled the foreign press. The "unsmiling fuehrer," said Thompson, seemed

See George T. Blakey, Historians on the Homefront: American Propagandists for the Great War (Lexington: University Press of Kentucky, 1970), 98-105.

${ }^{59}$ Topeka Journal, March 6, 1918.

${ }^{60}$ About 75 photographs are in the Red Cross Collection at the Library of Congress Prints and Photographs Division.

${ }^{61}$ Topeka State Journal, July 10, 1920.

${ }^{62}$ Interview with Thompson's relative, Lester William Burton, of Topeka, Kansas, April 1982. Some still photographs from the China trip are in the Donald Thompson file at the Kansas State Historical Society in Topeka. 
ill at ease, but Mussolini was "a born showman" who got on well with the correspondents. ${ }^{63}$ Thompson said he was planning to leave for China to cover the Nationalist government's resistance to the Japanese. This may have been his last foreign adventure; his photographs of the Japanese attack on Shanghai have been preserved, but no film or stills shot after this time have been found. He seems to have retired before the beginning of World War Two and died in southern California in July $1947 . .^{64}$

[Note: This article, a new introduction to the re-publication of Donald Thompson in Russia, forthcoming from Slavica Publishers in its series on Americans in Revolutionary Russia is included here by permission of the author and the press.

David H. Mould, a British-born journalist, is professor emeritus of media studies at Ohio University. His American Newsfilm, 1914-1919 (Routledge, 1984), featuring Thompson, was republished in 2014. In recent years he has traveled extensively in Madagascar and Central Asia. A book on the latter, Postcards from Stanland, was published last year by Ohio University Press. A lecture, "Images of World War One: The Films of Pioneer Kansas Photographer Donald Thompson" was very well received at the University of Kansas last month. Norman Saul]

63 "Man Who Has Interviewed Dictators Gives Views Here," St. Joseph (Missouri) Gazette, April 7, 1937. See also Wichita Eagle, May 17, 1936.

${ }^{64}$ California Death Index, Los Angeles County, state file number 47-52543. 